\title{
Growth and Immune Gene Expression by Dietary Supplementation of Mannan Oligosaccharide in Fry of Deccan Mahseer, Tor khudree
}

\author{
A. B. Ranadive*, S. J. Meshram, R. M. Tibile, R. K. Pai and S. K. Hundare
}

Department of Aquaculture, College of Fisheries (DBSKKV), Shirgaon, Ratnagiri, Maharashtra (415 629), India

\section{Corresponding Author}

A. B. Ranadive

e-mail: aish0609@yahoo.in

\author{
Article History \\ Article ID: AR1926 \\ Received in $29^{\text {th }}$ October, 2018 \\ Received in revised form $27^{\text {th }}$ November, 2018 \\ Accepted in final form $29^{\text {th }}$ November, 2018
}

\begin{abstract}
The present study was conducted during 2017 at wet laboratory of College of Fisheries, Shirgaon, Ratnagiri, Maharashtra, India to evaluate the effect of mannan oligosaccharide on growth and immune gene expression in fry of Deccan mahseer, Tor khudree (Sykes, 1839). In the experiment the fry $(0.067 \pm 0.02 \mathrm{~g})$ were stocked at a rate of $30 \mathrm{fry} / 50 \mathrm{~L}$ in a plastic tub. The fry was fed with $38 \%$ protein diet incorporated with different levels of $\operatorname{MOS}\left(0.0 \mathrm{~g} \mathrm{~kg}^{-1}, 1.5 \mathrm{~g} \mathrm{~kg}^{-1}, 3.0 \mathrm{~g} \mathrm{~kg}^{-1}\right.$ and $\left.4.5 \mathrm{~g} \mathrm{~kg}^{-1}\right)$. The fry was fed for 60 days at a rate of $4 \%$ of body weight twice a day. The water was exchanged once a day that is in morning session to remove the uneaten feed and faecal matter. Among the experimental diets, the diet containing $3.0 \mathrm{~g} \mathrm{~kg}^{-1} \mathrm{MOS}$ showed significantly higher growth as weight gain (402.43 \pm 15.17$)$, length gain (70.023 \pm 0.75$)$, specific growth rate $(2.62 \pm 0.05)$, average daily growth rate $(0.282 \pm 0.80)$ and survival percentage $(81.99 \pm 1.3)$ as compared to other diets. Feed conversion ratio was better in diet containing $3.0 \mathrm{~g} \mathrm{~kg}^{-1}$ of MOS but there was no significant difference among the diets. In the immune gene expression study the primer were designed for the RT-PCR. Among which the housekeeping gene $\beta$-actin was amplified at $59{ }^{\circ} \mathrm{C}$. The above results indicate that incorporation of MOS at a rate of $3.0 \mathrm{~g} \mathrm{~kg}^{-1}$ of feed in diets of Deccan mahseer fry could enhance the growth performance and the feed conversion ratio.
\end{abstract}

Keywords: Mannan oligosaccharide, Tor khudree, fry, growth, gene expression

\section{Introduction}

Mahseers are considered as potential candidate species for aquaculture, especially in the wake of the recent push toward the culture of indigenous species. Deccan Mahseer (Tor khudree) is one of the important coldwater fish species having market demand as a food fish and for recreational fisheries in India. Recently the fish is paid special attention due to its rapid disappearance from natural habitat and also ecological alterations and physical changes in natural environment (Kulakarni and Ogale, 1995). The artificial breeding and hatchery production of fry and fingerling were thought to be the only means to ensure their conservation and replenishment of stock in rivers (Ogale, 1997). Artificial propagation, distribution of resultant fingerling into different waters and ranching could be timely and promising measures to rehabilitate the endangered species. Therefore, production of good quality fingerlings with better growth and survival is the prime need for management of endangered mahseer (Kulkarni, 1989). The latest version of the IUCN Red List of Threatened Species has listed Tor khudree for the first time in the year 2007 as endangered because of a $60-70 \%$ decline in the native wild population during the past three generations, as a result of exploitation and habitat destruction. Commercial expansion of this species for aquaculture and stock enhancement in the natural waters requires special attention. The main bottleneck in the process is the limitation of optimum sized fingerlings for grow out or ranching into the natural waters.

Outbreak of disease is the major problem in freshwater aquaculture. India faces significant economic loss due to bacterial infection (Swain et al., 2002). The bacterial flora responsible for disease was predominantly gram -ve (75\%) bacteria (Phatarpekar et al., 2002). Aeromonas, Alcaligenus and Pseudomonas were the most frequently observed genera. Within Pseudomonas, Pseudomonas fluorescens and Pseudomonas aeruginosa are known to cause disease in freshwater fishes (Saharia and Prasad, 2001; Swain et al., 2007). Infection of these bacteria leads to the development of septicaemia and ulcerative conditions, especially when the fishes are under stress or injured by inappropriate handling. Shahi and Mallik (2014) observed eye lesions in golden mahseer, Tor putitora, caused due to infection of Pseudomonas koreensis. 
Previously, diseases were treated with antibiotics; however it poses threats to environment by developing resistance in pathogens and also creating food residual problem, which affects the health of consumer (FAO, 2002). Therefore, stimulation of non-specific immunity by immunostimulants is one of the choices. It will help to increase resistance to infectious diseases by enhancing non-specific defence mechanisms (Sakai, 1999).

Proper nutrition is a prerequisite for fish culture industry. Artificial diets with supplementation of nutraceutical will help to provide essential nutrients as well as help to increase immune response in fish during culture (Gatlin, 2002; Paliyath et al., 2012).

The nutraceuticals like immunostimulants are widely used in aquaculture. Immunostimulants such as probiotics, anti-stress products, herbal products and prebiotics help to enhance the immunity of aquatic organisms (Sakai, 1999). Prebiotics are non-digestible oligosaccharides and polysaccharides, which promote the growth of beneficial lactic acid bacteria in the colon and exert antagonism to Salmonella spp. or Escherichia coli, which ultimately helps in limiting their proliferation. It includes nutraceuticals like mannan oligosaccharide (MOS) and $\beta$-glucan which are derived from yeast, Saccharomyces cerevisiae.

Prebiotics have several advantages, but the main advantage of prebiotics over probiotics is that they are natural feed ingredients. Their incorporation in the diet does not require particular precautions and their authorization as feed additives may be more easily obtained, in spite of some concerns about their safety and efficacy (Gatesoupe, 2005). Mannan oligosaccharide (MOS) is defined as a prebiotic because it is a nondigestible food ingredient which positively influences the host organism by stimulating growth and activity of one or more bacteria in gut, promoting growth, nutrient utilization and health improvement (Gibson and Roberfroid, 1995). The mannan oligosaccharide (MOS) is an oligosaccharide characterized as a carbohydrate complex derived from glucomannan proteins of yeast outer cell wall (Sohn et al., 2000). The results of MOS on growth, systemic immunity and gut mucosa are considered sufficient to avoid the costs of curative measures besides decrease the microbiological problem of the misuse of antibiotics.

\section{Materials and Methods}

The experiment was conducted during 2017 at wet laboratory of College of Fisheries, Shirgaon, Ratnagiri, Maharashtra, India. Fry of Deccan mahseer Tor khudree were obtained from Tata Electric Company's Fish Farm, Walwan, District Pune, Maharashtra, India and maintained in plastic pools having 500 I capacity. They were acclimatised to laboratory conditions for 20 days. They were fed with the pellet feed containing $38 \%$ protein at a rate of $4 \%$ of the body weight twice a day. The water exchange was done twice a day at a rate of $20 \%$ to remove the uneaten feed and faecal matter. Diet was prepared by using the same composition of ingredients described by Meshram et al. (2015). The ingredients were individually powdered and weighed according to the composition of diet and mixed thoroughly. Dough of mixed ingredients was prepared by heating in pressure cooker and press through the pelletiser $(1 \mathrm{~mm})$. The pellets were dried in the oven and the dried pellets were stored in the airtight container.

The Mannan Oligosaccharide was supplemented at a rate of $0.0,1.5,3.0$ and $4.5 \mathrm{~g} \mathrm{~kg}^{-1}$ of feed and the diet without Mannan Oligosaccharide served as a control diet. The test diets were served as $\mathrm{T}_{1}$ (control), $\mathrm{T}_{2}\left(1.5 \mathrm{~g} \mathrm{~kg}^{-1}\right), \mathrm{T}_{3}\left(3.0 \mathrm{~g} \mathrm{~kg}^{-1}\right)$ and $\mathrm{T}_{4}(4.5$ $\mathrm{g} \mathrm{kg}^{-1}$ ) (Table 1). The method of diet preparation was similar to that of control diet.

\begin{tabular}{llcccc}
\hline \multicolumn{6}{l}{ Table 1: Proportion of ingredients in test diet } \\
\hline SI. No. & Ingredients & $\mathrm{T}_{1}$ & $\mathrm{~T}_{2}$ & $\mathrm{~T}_{3}$ & $\mathrm{~T}_{4}$ \\
\hline 1. & Fish meal & 20.51 & 20.51 & 20.51 & 20.51 \\
2. & Soybean meal & 20.51 & 20.51 & 20.51 & 20.51 \\
3. & Groundnut oil & 20.51 & 20.51 & 20.51 & 20.51 \\
& cake & & & & \\
4. & Shrimp waste & 28.73 & 28.73 & 28.73 & 28.73 \\
5. & $\quad$ Rice bran & 28.73 & 28.58 & 28.43 & 28.28 \\
6. & $\quad$ Wheat flour & 28.73 & 28.73 & 28.73 & 28.73 \\
7. & $\quad$ Mannan oligo- & 0.0 & 0.15 & 0.30 & 0.45 \\
& $\quad$ saccharide & & & & \\
8. & Vit. Min. mixa & 1 & 1 & 1 & 1 \\
\hline
\end{tabular}

a. Vit. Min. mix (per kg): vit. A: 700000 IU; Vit. $D_{3}$ : $70000 I U$; Vit. E: $250 \mathrm{mg}$; Cobalt: $150 \mathrm{mg}$; Copper: $1200 \mathrm{mg}$; lodine: 325 mg; Iron: 1500 mg; Mangesium: 6000 mg; Potassium: $100 \mathrm{mg}$; Sodium: $5.9 \mathrm{mg}$; Manganese: $1500 \mathrm{mg}$; Sulphur: 0.72\%; Zinc: 9600 mg; DL. Methionine: 1000 mg; Calcium: 25.5\%; Phosphorus: $12.75 \%$

\subsection{Experimental procedure}

\subsubsection{Experiment-I}

\subsubsection{Effect of dietary supplementation of Mannan} Oligosaccharide on growth and survival of T. khudree

The fishes were stocked in the 50 I FRP tank at a rate of 30 fry/tank. The fry fed with test diets at a rate of $4 \%$ of the body weight twice a day for 60 days. The water quality was maintained by daily water exchange at a rate of $25 \%$. The water exchange was done in the morning prior to feeding to remove the uneaten feed and the faecal matter. Each tub was aerated with one diffuser type of air stone. Water temperature and $\mathrm{pH}$ were measured daily by using clinical mercury thermometer and $\mathrm{pH}$ meter ( $\mathrm{pH}$ meter EQ 610).

\subsubsection{Growth and survival}

The initial and final weight of fry was measured individually (Satrorious BS 224S). Similarly, initial and final lengths were 
recorded individually by using metallic scale. The live weight gain (\%), length gain (\%). Specific growth rate (SGR), Average daily growth (ADG) and survival (\%) were calculated.

\subsubsection{Experiment - II}

2.1.2.1. Immune gene expression by dietary supplementation of MOS

The fry which were fed with the experimental diets for 60 days were used for the immune gene expression study. At the end of the feeding experiment, three fingerlings from each tank were randomly collected. The tissue sample was collected from the liver and intestine of the fingerlings and immediately placed in a morter containing liquid nitrogen and crushed with pestle. That sample was utilised for total RNA isolation. Tissue sample of $100 \mathrm{mg}$ was utilised to isolate RNA by using trizol reagent. After homogenization, $0.2 \mathrm{ml}$ of chloroform $/ \mathrm{ml}$ of trizol was added. The sample was centrifuged for $15 \mathrm{~min}$ at $4{ }^{\circ} \mathrm{C}$. The supernant was utilised and to which 0.25 volume of isopropanol was added. The sample tubes were again centrifuged. The pellets were washed with $75 \%$ Ethanol and air dried. About $50-100 \mu$ l of DEPC treated water was added to the pellets and stored at $-70^{\circ} \mathrm{C}$. The sample was quantified by using spectrophotometer and the quality was checked by running the sample through $1 \%$ Agarose gel (GeNei ${ }^{\mathrm{TM}}$ mini pack 250). From total RNA, 1-3 $\mu$ g was taken and treated with DNase followed by cDNA synthesis. First step was to add Oligo (dt) ${ }_{18}$ primers followed by the incubation at $65^{\circ} \mathrm{C}$ for 5 min. and then in that template, dNTPs, RNase inhibitor and reverse transcriptase enzyme were added. This was incubated for $60 \mathrm{~min}$ at $42{ }^{\circ} \mathrm{C}$ and inactivation of reverse transcriptase was done by heating the reaction to $70^{\circ} \mathrm{C}$ for $5 \mathrm{~min}$. Forward and reverse primers were designed on the available cDNA sequences in $\mathrm{NCBI}$ for immune genes of particular species or related species for immune genes $L G B P, M B L, C O P B_{2}$ and $S O D$ using gene runner (3.2) software. Gapdh/ $\beta$-actin was used as housekeeping gene.

\subsection{Statistical analysis}

Experiment was conducted by following completely randomised design with five replicates. The growth and survival data were analysed by using SPSS software (Version 13.0) and means were compared by following Duncan's Multiple Range Test.

\section{Results and Discussion}

3.1. Experiment I: Effect of dietary supplementation of Mannan Oligosaccharide on growth and survival of $T$. khudree.

Mannan oligosaccharide is a glucomanno protein complex derived from the outer cell wall of the yeast Saccharomyces cerevisiae, which promotes growth of beneficial lactic acid bacteria in the colon. This way, it improves growth rate and immune system of the fish (Gibson and Robertfroid, 1995). In aquaculture, MOS as a feed additive were conducted on different species showing better improvement in growth, lesser mortalities and improved immune response.

In the present study, the optimum dietary MOS supplementation level for the mahseer was found to be 3.0 $\mathrm{g} \mathrm{kg}^{-1}$ of the diet. The percentage of length and weight gain of mahseer was found significantly higher than other diets in the experiment. Similar results were observed by RodriquezEstrada et al. (2009) they recorded the maximum weight and length gain in the diet with MOS supplementation of $0.4 \%$ of MOS in the rearing of rainbow trout (Onchohrinchus mykiss). Akrami et al. (2012) used gibel carp (Carrassius auratus gibelio) juveniles for their experiment and observed that the fish fed diet containing $0.45 \%$ of MOS showed higher weight gain. In tilapias (Oreochromis niloticus), Samrongpan et al. (2008) used different inclusion levels of MOS and observed the highest weight gain in diet containing $0.4 \%$ of MOS and lowest in the control diet. Positive influence of incorporation of MOS in diet has been also reported in Huso huso (Mohajer et al., 2010); Dicentrachus labrax (Torrecillas et al., 2011); Carrassius auratus gibelio (Akrami et al., 2012); Dicentrachus labrax (Torrecillas et al., 2013).

On the contrary, to the above facts, the channel catfish Ictalurus punctatus fed MOS $(0.2 \%)$ had no significant effect on weight and length gain (Welker et al., 2007). No significant differences $(p<0.05)$ were observed with the dietary supplementation of a Saccharomyces cerevisiae fermentation product, in the diet of sea bream (Sparus aurata) with respect to weight gain and length gain (He et al., 2009).

The results in the present study were comparable with the earlier work done, which showed that mahseer fry requires $3.0 \mathrm{~g} \mathrm{~kg}^{-1}$ of MOS for better weight and length gain.

In the present study, maximum specific growth rate of $2.62 \%$ was noticed at a $3.0 \mathrm{~g} \mathrm{~kg}^{-1} \mathrm{MOS}$ supplementation level and it declined again in $\mathrm{T}_{4}$ containing $4.5 \mathrm{~g} \mathrm{~kg}^{-1}$ of MOS to $2.14 \%$. Similar results were observed by Rodriquez-Estrada et al. (2009) that growth rate was high in fish fed of the $0.4 \%$ MOS inclusion in rainbow trout (Onchohrinchus mykiss). Similarly, Samrongpan et al. (2008) reported that addition of MOS at the level of $4 \%$ increases specific growth rate in tilapia. Muzlum et al. (2011) also reported that addition of MOS $0.3 \%$ in Astacus leptodactylus showed the higher specific growth rate than other treatments.

On the contrary no significant difference was observed in specific growth rate by He et al. (2009) in the dietary supplementation of a Saccharomyces cerevisiae fermentation product in sea bream (Sparus aurata). Dimitrilogue et al. (2009) also concluded by their study that specific growth rate was unaffected by the dietary supplementation of MOS $(0.2 \%$ and $0.4 \%$ ) in the diet of sea bream (Sparus aurata).

The results observed in the present study were comparable with earlier work done, which showed that mahseer fry requires $3.0 \mathrm{~g} \mathrm{~kg}^{-1}$ of MOS for better specific growth rate.

In the present study, maximum survival percentage of $81.99 \%$ 
was observed in mahseer fry. Similar results were observed in the works of Rodriquez-Estrada et al. (2009) (Onchorhynchus mykiss) and Akrami et al. (2012) (Carrassius auratus gibelio).

On the other hand no significant difference was observed by Peterson et al. (2012) in survival of channel catfish (Ictalurus punctatus) by supplementation of MOS $(0.4 \%)$ in the diet. There was also no significant difference observed between control and MOS treated group.

The results observed in the present study were comparable with earlier work done, which showed that mahseer fry requires $3.0 \mathrm{~g} \mathrm{~kg}^{-1}$ of MOS for better survival percentage.

The better feed conversion ratio was observed in the present study in $\mathrm{T}_{3}$ having $3.0 \mathrm{~g} \mathrm{~kg}^{-1}$ MOS inclusion in the diet. Rodriquez-Estrada et al. (2009) observed the lowest feed conversion ratio in the inclusion level of $0.4 \% \mathrm{MOS}$ in the diet of rainbow trout. Muzlaum et al. (2011) also reported the better feed conversion in the diet containing $0.3 \%$ of MOS than other treatments in the rearing of Astacus leptodactylus.

On contrary no significant difference were observed by Dimitrilogue et al. (2009) that the feed conversion ratio by the dietary supplementation of MOS $(0.2 \%$ and $0.4 \%)$ in the diet of sea bream (Sparus auratus).

The results observed in the present study were comparable with earlier work done, which showed that mahseer fry requires $3.0 \mathrm{~g} \mathrm{~kg}^{-1}$ of MOS for better feed conversion ratio.

Hence, the results suggest that dietary supplementation of MOS at $3.0 \mathrm{~g} \mathrm{~kg}^{-1}$ diet has been significantly improved the growth performance and feed utilization in mahseer (Table 2).

\begin{tabular}{llcccc}
\hline \multicolumn{6}{l}{ Table 2: Growth performance and survival rate } \\
\hline Sl. No. & parameters & $\mathrm{T}_{1}$ & $\mathrm{~T}_{2}$ & $\mathrm{~T}_{3}$ & $\mathrm{~T}_{4}$ \\
\hline 1. & Length gain & $2.74 \pm 0.04^{\mathrm{a}}$ & $2.64 \pm 0.04^{\mathrm{a}}$ & $2.86 \pm 0.01^{\mathrm{b}}$ & $2.65 \pm 0.02^{\mathrm{a}}$ \\
2. & Weight gain & $0.266 \pm 0.006^{\mathrm{a}}$ & $0.235 \pm 0.012^{\mathrm{b}}$ & $0.283 \pm 0.003^{\mathrm{c}}$ & $0.229 \pm 0.003^{\mathrm{a}}$ \\
3. & SGR & $2.316 \pm 0.09^{\mathrm{a}}$ & $2.516 \pm 0.05 \mathrm{~b}$ & $2.628 \pm 0.05^{\mathrm{b}}$ & $2.147 \pm 0.03^{\mathrm{a}}$ \\
4. & ADG & $0.234 \pm 0.01^{\mathrm{a}}$ & $0.265 \pm 0.006^{\mathrm{b}}$ & $0.282 \pm 0.003^{\mathrm{c}}$ & $0.228 \pm 0.003^{\mathrm{a}}$ \\
5. & FCR $^{*}$ & $0.946 \pm 0.07$ & $0.937 \pm 0.08$ & $0.871 \pm 0.02$ & $0.969 \pm 0.10$ \\
6. & Survival rate & $77.99 \pm 0.8^{\mathrm{b}}$ & $81.33 \pm 1.4^{\mathrm{c}}$ & $81.99 \pm 1.3^{\mathrm{c}}$ & $71.99 \pm 0.8^{\mathrm{a}}$ \\
\hline
\end{tabular}

*Non-significant ( $p>0.05)$; All values are mean_SE of three observations; Mean bearing different superscript in a row differ significantly $(p<0.05)$

\subsection{Experiment II: Effect of MOS on immune gene expression of $T$. khudree}

In present study, the primers for immune gene expression evaluation faced general problems. The primers were designed using the sequences from other cyprinid fishes because the gene sequences of Tor khudree were not reported. The expected sequence differences between the cyprinids and Tor khudree lead to problems due to mismatch between primer and target sequence, which resulted in complete failure of PCR.

The primers were tested in PCR with cDNA. They were supposed to amplify a single product with a cDNA template. All primers tested did not amplify the cDNA except the primer of $\beta$-actin. The reason for that may be due to absence of exon-intron boundaries in this sequence. The DNase digestion during mRNA extraction was not always satisfactory. Therefore some of the samples contained cDNA and gDNA during PCR. This explains why it was not possible to amplify all immune genes. In the present study, it was possible to amplify only $\beta$-actin at $59^{\circ} \mathrm{C}$ as compared to other immune genes.

The similar problem was faced by Hibbeler et al. (2008) while evaluating the housekeeping genes for quantitative expression studies in the three-spined sickleback (Gasterosteus aculeatus) (Table 3).

\begin{tabular}{|c|c|c|c|c|}
\hline $\begin{array}{l}\text { Sl. } \\
\text { No. }\end{array}$ & $\begin{array}{l}\text { Primer } \\
\text { name }\end{array}$ & Primer Sequence $5^{\prime}$ to $3^{\prime}$ & $\begin{array}{l}\text { No. of } \\
\text { Bases }\end{array}$ & $\begin{array}{l}\mathrm{Tm} \\
\left({ }^{\circ} \mathrm{C}\right)\end{array}$ \\
\hline 1. & 5'FMBL & TCGGGACACTTCTGCTCCTTCA & 22 & 62.1 \\
\hline 2. & 5'RMBL & $\begin{array}{l}\text { ССАТСTTTACCATCTCTCCCA } \\
\text { ТСТСТTC }\end{array}$ & 28 & 65.1 \\
\hline 3. & 5'FSOD & $\begin{array}{l}\text { TTTGCTCTTGCTGTTACAG- } \\
\text { GTGATGTG }\end{array}$ & 27 & 63.4 \\
\hline 4. & 5'RSOD & $\begin{array}{l}\text { TGAAATCTCTCACCCTGTG- } \\
\text { GTTCTCCTC }\end{array}$ & 28 & 66.6 \\
\hline 5. & 5'FLPS & $\begin{array}{l}\text { TGCCTTTACCATCAACTCAG- } \\
\text { CAGG }\end{array}$ & 24 & 62.7 \\
\hline 6. & 5'RLPS & $\begin{array}{l}\text { CAGTGATGTAGAGGGAAAG } \\
\text { GGCA }\end{array}$ & 23 & 62.4 \\
\hline 7. & $\begin{array}{l}5^{\prime} \\
\mathrm{FCOPB}_{2}\end{array}$ & $\begin{array}{l}\text { AGCACTCTGAGATTCAGCAG- } \\
\text { GCAAAC }\end{array}$ & 26 & 64.8 \\
\hline 8. & $\begin{array}{l}5^{\prime} \\
\mathrm{RCOPB}_{2}\end{array}$ & $\begin{array}{l}\text { CCACCACAAACCTGCCGT- } \\
\text { TAGG }\end{array}$ & 22 & 64.0 \\
\hline 9. & $\begin{array}{l}5^{\prime} F \beta- \\
\text { actin }\end{array}$ & $\begin{array}{l}\text { AGCAGATGCCTCATGCAGTC } \\
\text { CTCAC }\end{array}$ & 25 & 66.3 \\
\hline 10. & $\begin{array}{l}5^{\prime} \mathrm{R} \\
\beta \text {-actin }\end{array}$ & $\begin{array}{l}\text { TGCTCTGAGCCTCATCAC- } \\
\text { CAACG }\end{array}$ & 23 & 64.2 \\
\hline
\end{tabular}




\subsubsection{Gene amplification}

The PCR reaction was set as per the $\mathrm{Tm}$ of the primers $\left( \pm 5^{\circ} \mathrm{C}\right)$. The conditions were set according to the steps followed in PCR (Table 4 and Figure 1). The amplification of $\beta$-actin was done successfully at $59^{\circ} \mathrm{C}$. The remaining primers were not successfully amplified because of the continuous dimer formation in PCR. Therefore, the RT-PCR work was not carried out. Further studies are required for the amplification of the primers.

\begin{tabular}{llcc}
\hline \multicolumn{4}{l}{ Table 4: PCR protocol for amplification of $\beta$-actin } \\
\hline Sl. No. & Step & Temperature /Time & Cycles \\
\hline 1. & Denaturation & $94^{\circ} \mathrm{C} / 5 \mathrm{~min}$ & 1 \\
2. & Denaturation & $94^{\circ} \mathrm{C} / 30 \mathrm{sec}$. & 40 \\
3. & Annealing & $59^{\circ} \mathrm{C} / 30 \mathrm{sec}$. & \\
4. & Extension & $72^{\circ} \mathrm{C} / 30 \mathrm{sec}$. & \\
5. & Final Extension & $72^{\circ} \mathrm{C} / 5 \mathrm{~min}$ & 1 \\
6. & Hold & $4^{\circ} \mathrm{C} / \infty$ & \\
\hline
\end{tabular}

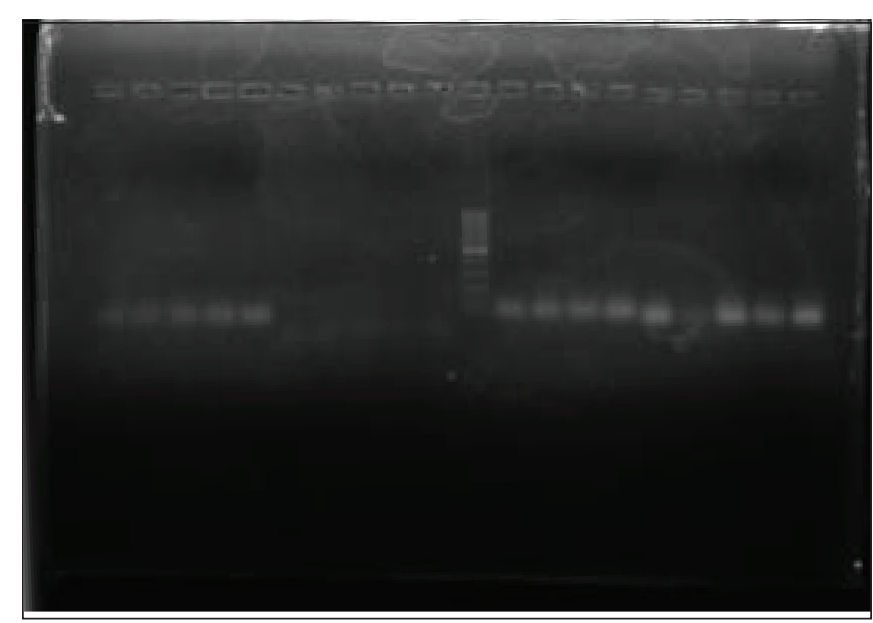

Figure 1: Dimer formation in PCR

\section{Conclusion}

Deccan mahseer T. khudree fed diet containing 38\% crude protein and $3.0 \mathrm{~g} \mathrm{~kg}^{-1}$ of MOS supplementation showed better growth (length gain, weight gain, specific growth rate and average growth rate), survival and feed conversion ratio. The results suggest that dietary supplementation of MOS at a level of $3.0 \mathrm{~g} \mathrm{~kg}^{-1}$ significantly improved growth performance and feed utilization of fish. It can be also suggested that the $\beta$-actin primer can be amplified at $59^{\circ} \mathrm{C}$.

\section{Acknowledgment}

The authors are thankful to the faculty of College of Fisheries, Shirgaon, Ratnagiri, Maharashtra, India for their constant support and encouragement during the research work.

\section{References}

Akrami, R., Chitsan, H., hezarjaribi, A., Ziaei, R., 2012.
Effects of dietary Mannan oligosaccharide (MOS) on growth performance and immune response of Gibel carp juveniles (Carrassius auratus gibelio). Journal of Veterinary Advances 2, 507-513.

Dimitroglous, A., Merrifield, D.L., Spring, P., Sweetman, J., Moate, R., Davies, S.J., 2009. Effects of mannanoligosaccharide (MOS) supplementation on growth performance, feed utilisation, intestinal histology and gut microbiota of gilthead sea bream (Sparus aurata). Aquaculture 300, 182-188.

FAO, 2002. Antibiotics residue in aquaculture products. The State of World Fisheries and Aquaculture, Rome, Italy, 74-82.

Gatesoupe, F.J., 2005. Probiotics and prebiotics for fish culture, at the parting of the ways. Aqua Feeds: Formulation \& Beyond 2, 3-5.

Gatlin, D.M.III., 2002. Nutrition and fish health. In: Halver, J.E., Hardy, R.W. (Eds.), Fish Nutrition, Academic Press, San Diego, CA, USA, 671-702.

Gibson, G.R., Roberfroid, M.B., 1995. Dietary modulation of the human colonic microbiota: introducing the concept of prebiotics, Journal of Nutrition 125, 1401-1412. DOI: 10.1093/jn/125.6.1401.

He, S., Zhou, Z., Liu, Y., Shi, P., Yao, B., Ringo, E., Yoon, I., 2009. Effects of dietary Saccharomyces cerevisiae fermentation product (DVAQUA ${ }^{\circledR}$ ) on growth performance, intestinal autochthonous bacterial community and non-specific immunity of hybrid tilapia (Oreochromis niloticusxOreochromis aureus) cultured in cages. Aquaculture 294, 99-107. DOI: 10.1016/j. aquaculture.2009.04.043.

Hibbeler, S., Scharsack, J.P., Becker, S., 2008. Housekeeping genes for quantitative expression studies in the threespined stickleback Gasterosteus aculeatus. Molecular Biology, 8-18. DOI: 10.10.1186/1471-2199-9-18.

Kulkarni, C.V., 1989. Role of aquaculture in the conservation of mahseer fisheries. In: recent research in cold water fisheries Nat. Workshop on Res. And Dev. Need cold water fisheries, 30 January-31 January 1989, Today and Tomorrow, 173-176.

Kulkarni, C.V., Ogale, S.N., 1995. The present status of mahseer. Conservation of mighty mahseer of India. Tata Press Ltd. Bombay 10, 651-660.

Mazlum, Y., Yilmaz. E., Genc, M.A., Guner, O., 2011. A preliminary study on the use of mannan oligosaccharide in freshwater Crayfish, juvenile. Aquaculture International 19, 111-119. DOI: 10.1007/s10499.010.9345.4.

Meshram, S.J., Shivananda Murthy, H., Ali, H., Swain H.S., Ballyaya, A., 2015. Effect of dietary beta-glucan on immune response and disease resistance against Aeromonas hydrophila in giant freshwater prawn, Macrobrachium rosenbergii (de Man, 1879). Aquaculture International 23, 439-447. DOI: 10.1007/s10499-0149824-0. 
Mohajer, E., Vahabzadeh, M., Zamani, H., Soudagar, A.A., Ghorbani, M., Nasrabadi, R., 2010. Effect of dietary immunogen prebiotics on growth and survival indices of giant sturgeon (Huso huso Linne, 1758) juveniles. Journal of Fisheries 4, 610-672.

Ogale, S.N., 1997. Induced spawning and hachting of golden mahseer Tor pitutora (Hamilton) at Lonavla, Pune District (Maharashtra) in Western Ghats. Fishing Chimes, 27-29.

Paliyath, G., Bakoviv, M., Shetty, K., 2012. Functional foods, nutraceuticals and degenerative disease prevention. Wiley Blackwell.

Peterson, B.C., Booth, N.J., Barrows, F.T., Manning, B.B., 2012. Improved survival in channel catfish fed with mannanoligosaccharides in an extruded diet. Open Journal of Animal Sciences 2(2), 57-61. DOI:10.4236/ ojas.2012.22009.

Phatarpekar, P.V., Kenkre, V.D., Sreepada, R.A., Desai, U.M., Achuthankutty, C.T., 2002. Bacterial flora associated with larval rearing of the giant freshwater prawn, Macrobrachium rosenbergii. Aquaculture 203, 279-291. DOI: 10.1016/S0044-8486(01)00750-0.

Rodrigues-Estrada, U., Satoh, S., Haga, Y., Fushimi, H., Sweetman, J., 2009. Studies of the effects of mannanoligosccharides, Enterococcus feacalis and poly hydrobutyric acid as immune stimulant and growth promoting ingredients in rainbow trout diets. Aquaculture Science 57, 609-617. DOI: 10.11233/ aquacultureresci.57.609.

Saharia, P.K., Prasad, K.P., 2001. Development of coagglutination kit for the diagnosis of Pseudomonas fluorescens infection in fishes. Asian Fisheries Science 14, 293-300.

Sakai, M., 1999. Current research status of fish immunostimulants. Aquaculture 172, 63-92. DOI: 10.1016/s0044-8486(98)00436-0.

Samrongpan, C., Arrechon, N., Yoonpundh, R., Sirsapoome, P., 2008. Effects of mannanoligosaccharides on growth, survival and disease resistance of Nile tilapia (Oreochromis niloticus) fry. $8^{\text {th }}$ Interantional symposium on tilapia in aquaculture 2008. Cairo, Egypt, 345-353.

Shahi, N., Mallik, S.K., 2014. Recovery of Psuedomoas koreensis from eye lesions in Golden Mahseer, Tor putitora (Hamilton, 1822), in Uttarakhand, India. Journal of Fish Diseases 37, 497-500. DOI: 10.1111/jfd.12126.

Sohn, K.S., Kim, M.K., Kim, J.D., Han, I.K., 2000. The role of immunostumulants in monogasrtic animal and fishreview. Asian-Australian Journal of Animal Science 13, 1178-1187.

Swain, P., Nayak, S.K., Shahu, A., Mohapatra. B.C., Meher, P.K., 2002. Bath immunization of spawns, fries and fingerlings of Indian major carps using a particulate antigen and determination of age, dose and duration of antigen exposure. Fish and Shellfish Immunology 13, 133-140. DOI: 10.1006/fsim.2001.0388.

Swain, P., Behura, A., Dash, S., Nayak, S.K., 2007. Serum antibody response of Indian major carp, Labeo rohita to three species of pathogenic bacteria: to three species of pathogenic bacteria: Aeromonas hydrophila, Edwardsiella tarda and Psuedomonas flurescens. Veterinary Immunology and Immunopathology 117, 137-141. DOI: 10.1016/j.vetimm.2007.02.010.

Torrecillas, S., 2011. Effects of dietary mannan oligosaccharides (MOS) on European sea bass (Dicentrachus labrax) juvenile culture. PhD thesis submitted in University of Las Palmas de Gran Canuria. DOI: 10.1111/j.13652095.2009.00730.x.

Torrecillas, S., Makol, A., Betancor, M.B., Montero, D., Caballero, M.J., Sweetman, J., Izquierdo, M., 2013. Enhanced intestinal epithelium barrier health status on European sea bass (Dicenrtacus labrax) fed mannan oligosaccharides. Fish \& shellfish Immunology 34, 1485-1495. DOI: 10.1016/j.fsi.2013.03.351.

Welkar, T.L., Lim, C., Yildirim, M., Shelby, R., Klesius, P.H., 2007. Immune response and resistance to stress and Edwardsiella ictulluri challenge in channel catfish, fed diets containing commercial whole-cell yeast or yeast subcomponents'. Journal of the world aquaculture Society 38, 24-35. DOI: 10.1111/j.17497345.2006.00070.x. 